\title{
The contribution of FDI in the Algerian economy
}

\author{
Brahimi Houda $^{1}$, Hua Jian ${ }^{2}$, Lemtaouch Latifa ${ }^{3}$ \\ Business School, Hohai University, Nanjing, China
}

\begin{abstract}
The literature on the effects of FDI in developing countries provides a range of prospective benefits to the recipient country, however many benefit of FDI are frequently challenged. The orientation to the market economy adopted by the Algerian government in the early nineties, and its desire to investment development allow it to attempt to attract FDI by giving many incentives. This paper examines qualitatively the extent to which Algeria benefits from the FDI attracted since the progressive economic reform and the opening process. The major conclusions stand out from this paper are as follow: (a) Algeria has not yet reached to attract the desired level of foreign investments. (b) Most of the foreign projects focus on the hydrocarbon sector. (c) The lack of the absorptive capacity of the Algerian economy. All these factors together hamper the potential spillover benefits from FDI.
\end{abstract}

Key words: economic growth, FDI, job creation, national investment.

\section{Introduction}

Foreign Direct Investment (FDI) became an important financial source for capital projects, vital for Emerging country's development. According to OECD definitions, FDI is a category of investment that reflects the objective of establishing a lasting interest by a resident enterprise in one economy (direct investor) in an enterprise (direct investment enterprise) that is resident in an economy other than that of the direct investor, the lasting interest implies the existence of a long term relationship between the direct investor and the direct investment enterprise and a significant degree of influence on the management of the enterprise. The direct or indirect ownership of $10 \%$ or more of the voting power of an enterprise resident in one economy by an investor resident in another economy is evidence of such a relationship. The provision of incentives (tax incentives, and/or subsidies) and the adoption of FDI stimulating policies stem from the expectation that FDI will bring tremendous benefits to the recipient countries (Azman Saini, Ahmed Zoubaidi and Siong Hook Law, 2010) $)^{[1]}$ by enhancing the economic growth. Andreas Johnson (2005) suggests that there are two mechanisms through which the FDI growth enhancing effect may take place, first, the FDI growth nexus might involve an impact of FDI on capital accumulation, in this case the impact of FDI depends only on its influence on domestic investment, second beyond its direct role on capital accumulation, FDI is expected to be growth enhancing by increasing productivity in host countries through technology transfers. The interaction between transnational corporations (TNCs) and domestic firms in developing countries can results in higher rates of knowledge and technology diffusion, thanks to the number of mechanisms, such as imitation, increased competition, training and human resources mobility (UNCTD, Geneva, 2010$)^{[2]}$. Kjetil Bjorvatn, Hans Jarle 
Kind and Hildegunn Kyvik Nordås (2002)

${ }^{[3]}$ state that local suppliers may be able to provide intermediates to foreign affiliates and over time, these supplies may become more and more skill intensive. Roland Craigwell (2006) ${ }^{[4]}$ suggests that an increase in FDI leads to higher employment. It has been pointed out in many studies that FDI spillovers do not appear automatically, but depend on the host countries absorptive capacity (Magnus Blomsterom \&Ari Kokko, 2003) ${ }^{[5]}$. FDI in the primary sector tend to have a negative effect on growth while investment in manufacturing a positive one, an evidence from the FDI in the service sector is ambiguous (Alfaro, 2003) ${ }^{[6]}$. The potential spillover benefits from FDI are realized only if local firms have the ability and motivation to invest in absorbing foreign technologies and skills, to motivate subsidization of foreign investment, it is therefore necessary at the same time, to support learning and investment in local firms as well (Magnus Blomsterom \&Ari Kokko, 2003 $)^{[7]}$. E.Borenztein, J.De Gregorio, J-W.lee (1998) ${ }^{[8]}$ suggest that the higher productivity of FDI holds only when the host country has a minimum threshold stock of human capital. Thus FDI contributes to economic growth only when a sufficient absorptive capability of the technologies is available in the host country. Among local country conditions Laura al (2003) $)^{[9]}$, herms and lensink $(2003)^{[10]}$, Mohammed Omran and Ali Bolbol (2003) ${ }^{[11]}$, Christer and Junjie (2007) $)^{[12]}$, Mohammed Arshad Khan (2007) $^{[13]}$ examined the intermediary role played by local financial institutions in channeling the contributions of FDI to economic growth, they argued that the lack of development of local financial markets can limit the economy's ability to take advantage of potential FDI spillovers.
Like other developing countries, Algeria wants to benefit from the advantages of foreign direct

\section{FDI in Algeria :overview}

\subsection{Trend and patterns of FDI}

The evolution of FDI inflow to Algeria can be divided into stages according to the analysis of the table's data. The period between 1993 to 1995 was characterized by a total absence of the FDI in Algeria due to the complicated situation of Algeria on the economic, politic, and social levels. This period witnessed the external indebtedness crisis aggravation, and therefore the raise of the external debt services which exceeded the available payment capacities, so that, the authorities were forced reschedule the external debts, which was followed with a strict application of the structural reform conditions made by the International Monetary Fund. Besides that, the deterioration of the security situations, as well as the political instability during that time had negatively affected the attraction of the FDI. Under this situation as well as the economic instability and the high risk, FDI would never be attracted even if better financial and tax motives have been given. The period between 1996 -2000 has been characterized by the inflow of the FDI to Algeria which estimated to 270 and 438 million dollars mostly consecrated in oil sector [15], so that Algeria wasn't attractive to the FDI in the other sectors. In the same time, Algeria was too far from the level reached by the Neighboring countries like Morocco where the FDI volume was in 1997 four times higher than in Algeria. While the fact of the FDI inflow to China is incomparable with the one of Algeria, since China got what is estimated to USD 41 billion in 2000, the equivalent of 93 times of the FDI inflow to Algeria in the same year. The period between 2001 and 2005 has known a 
remarkable improvement in the volume of the FDI inflow to Algeria since it surpassed USD 1 billion in 2001, 2002, 2005, at the same time Tunisia knew less FDI inflow than Algeria and more inflow to Morocco, except in 2002 when Algeria exceeded Morocco in the level of FDI inflow. According to the world investment report 2004 [16], Algeria was the third biggest FDI recipient in Africa in 2002, and the largest in the Maghreb region, this was mainly due to macroeconomic stabilization and economic liberalization implemented by the government in the early 1990s. However, its FDI inflows declined by $40 \%$ in 2003 (from USD 1065 million in 2002 to USD 633.8 million in 2003), so far, Algeria has not fully benefited from the downstream effects of FDI in term of local enterprises' competitiveness, job creation, domestic capital and technology transfer. Historically, a large part of investment went to oil and gas exploration. In the period between 2005 - 2011 after the decrease of the FDI inflow in 2010 by $17 \%$ after being estimated to USD 2761 million in 2009 , it increased again by $13.6 \%$ to get USD 2571 million in 2011, which represents $6 \%$ of the FDI inflow to the Arab countries, that is why Algeria got the fifth rank among the Arab countries in 2011, after the Saudi Arabia that got the first rank being the biggest welcoming country of the foreign investments by $38.2 \%$ among the total FDI inflow to Arab countries, followed by Emirates, then Lebanon, then Sudan, while

Morocco was the sixth after Algeria followed by Tunisia; Egypt got the 19th rank before Yemen and Libya which are in the last ranks [17]. The decline of the FDI inflow to Egypt is due to its recent bad political situation.

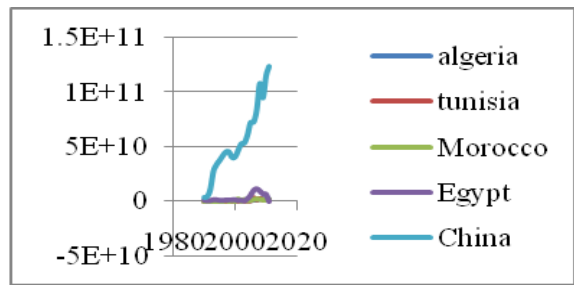

Fig.1 FDI inflow to Algeria versus other North African countries and china

Source: compiled by the author based on the UNCTAD data accessed on 2012

\subsection{Source country composition}

So far there have been many countries have FDI projects established in Algeria, like Arab countries, European countries mostly those of the European Union countries and Asian countries. The European Union countries are dominant in terms of project and capital with 190 projects with a value of 172550 million DZD (USD 3.703 billion) between 2002 and 2011, this because of the association agreement between Algeria and EU which was signed in 2002 and came into force on $1^{\text {st }}$ September $2005^{[18]}$, and that includes 36 French projects of 9 billion DZD (USD 0.122 million). As the second major investor in Algeria, Arab countries with 174 projects which represent DZD 1258036 million (USD 0.652 billion), among them 14 projects belong to Egyptian investors with DZD 48 billion (USD 0.652 billion). Emirate, Egypt, Saudi Arabia, Kuwait and Sultanate of Oman are considered as the most important Ar$\mathrm{ab}$ investors in Algeria in the number of projects, especially in the communication sector through Orascom Telecom Company of cell phone and some activities in services sector. USA occupied the fourth rank with 9 projects with the value of DZD 58821 million (USD 0.799 billion), in the same period of 2002 to 2011, after being the largest foreign investor in Algeria with more than USD 906 million 
(which is approximately the equivalent of DZD 63 billion) in the period 1998-2001; the American companies focus particularly on hydrocarbon sector, beside other sectors such as Pharmacy ${ }^{[19]}$.

Table 1: FDI inflow by countries in the period (2002-2011)

\begin{tabular}{|l|l|l|}
\hline & $\begin{array}{l}\text { Number of } \\
\text { projects }\end{array}$ & $\begin{array}{l}\text { Size (million DA) } \\
(1 \$=73.57 \mathrm{AD})\end{array}$ \\
\hline $\begin{array}{l}\text { European } \\
\text { countries }\end{array}$ & 230 & 313200 \\
\hline $\begin{array}{l}\text { European } \\
\text { union }\end{array}$ & 190 & 272550 \\
\hline $\begin{array}{l}\text { Arab } \\
\text { countries }\end{array}$ & 174 & 1258036 \\
\hline Asia & 31 & 512196 \\
\hline USA & 9 & 58821 \\
\hline $\begin{array}{l}\text { Multinational } \\
\text { corporation }\end{array}$ & 5 & 14641 \\
\hline $\begin{array}{l}\text { African } \\
\text { countries }\end{array}$ & 1 & 4.510 \\
\hline Australia & 1 & 2.974 \\
\hline Total & 451 & 2164378 \\
\hline
\end{tabular}

Source: $\underline{w w w . A N D I . d z}$ accessed on 2012

\subsection{Form of ownership and investment composition by sector}

According to the National Agency for Investment Development (ANDI) [20], the total of foreign projects is estimated with 451 projects, among which 209 of them are joint venture projects and 242 are wholly owned by foreigners. Regarding to the distribution of these projects on economic sectors, FDI projects are mainly implemented in industrial, services, Construction and public works sectors, which make together about 412 projects from a total of 451 with an amount of DZD 1570084 million (USD 21.341 billion) representing $72.54 \%$ of the total amount of foreign projects in Algeria, it is clear that despite the variety of other sectors that in which foreign investors work, hydrocarbon sector still the most attractive sector of the FDI, particularly after the Investment Law of 1991 that opened the door for the foreign investors to invest in energy and hydrocarbon sectors, in which the investment volume of the FDI reached USD1.8 billion in 2003, where Sonatrach company[21] signed 8 contracts during 2004 [22].

Table 2: FDI composition by sectors in the period (2002-2011)

\begin{tabular}{|l|l|l|l|l|}
\hline Sector & $\begin{array}{l}\text { Number } \\
\text { of pro- } \\
\text { jects }\end{array}$ & $\begin{array}{l}\text { \% of } \\
\text { total } \\
\text { number } \\
\text { of pro- } \\
\text { jects }\end{array}$ & $\begin{array}{l}\text { Capital } \\
\text { amount } \\
\text { (millions of } \\
\text { DZD)(1USD } \\
\text { = DZD } \\
73.57)\end{array}$ & $\begin{array}{l}\% \text { of } \\
\text { total } \\
\text { capital } \\
\text { amount }\end{array}$ \\
\hline $\begin{array}{l}\text { Agri- } \\
\text { culture }\end{array}$ & 8 & 1.77 & 6.533 & 0.30 \\
\hline $\begin{array}{l}\text { Con- } \\
\text { structio } \\
\text { n }\end{array}$ & 70 & 15.52 & 41981 & 1.94 \\
\hline Industry & 257 & 56.98 & 949710 & 43.88 \\
\hline Health & 3 & 0.67 & 8.589 & 0.40 \\
\hline $\begin{array}{l}\text { Transpo } \\
\text { rt }\end{array}$ & 16 & 3.55 & 9351 & 0.43 \\
\hline $\begin{array}{l}\text { Tour- } \\
\text { ism }\end{array}$ & 11 & 2.44 & 481321 & 22.24 \\
\hline $\begin{array}{l}\text { Ser- } \\
\text { vices }\end{array}$ & 85 & 18.85 & 578393 & 26.72 \\
\hline $\begin{array}{l}\text { Telec } \\
\text { ommuni } \\
\text { cation }\end{array}$ & 1 & 0.22 & 88500 & 4.09 \\
\hline \multicolumn{1}{|c|}{ Total } & 451 & 100 & 2164378 & 100 \\
\hline
\end{tabular}

Source: $\underline{w w w . a n d i . d z}$ accessed on 2012

\section{The contribution of FDI in Algeria's economy}

\subsection{FDI contribution in the national investment}

The number of investment projects declared by ANDI agency reached 47284 in the period between 2002-2011, among which 46833 are national projects representing $99.5 \%$ of the total projects, while 451 which represents $0.95 \%$ of the total investment projects are foreign investment projects. The weight of FDI projects has progressed slightly in 2011 representing $32.9 \%$ of the total amounts 
of capital invested in Algeria, after being $22 \%$ in 2005 . It is worth mentioning that although the few number of these projects, they constitute huge projects regarding their contribution in the invested capital amounts in Algeria due to the focus of the most of the projects on energy and oil sectors which need a huge amounts of capitals compared to the other sectors, despite that the attraction of foreign investments in other sectors took place in the recent years.

Table 3: Shares of FDI in total investment projects in the period (2002-2010)

\begin{tabular}{|l|l|l|l|l|}
\hline $\begin{array}{l}\text { Investment } \\
\text { projects }\end{array}$ & $\begin{array}{l}\text { Num- } \\
\text { ber of } \\
\text { projects }\end{array}$ & $\begin{array}{l}\text { \% of } \\
\text { total } \\
\text { invest- } \\
\text { vest- } \\
\text { ments }\end{array}$ & $\begin{array}{l}\text { Size of projects } \\
\text { (million of AD) } \\
\text { (1USD=73.57AD) }\end{array}$ & $\begin{array}{l}\text { \% total } \\
\text { size of } \\
\text { projects }\end{array}$ \\
\hline $\begin{array}{l}\text { National } \\
\text { investment }\end{array}$ & $\begin{array}{l}46 \\
833\end{array}$ & 99.05 & 4414144 & 67.10 \\
\hline $\begin{array}{l}\text { FDI } \\
\text { investment }\end{array}$ & 451 & 0.95 & 2164378 & 32.90 \\
\hline Total & 47 & 100 & 6578522 & 100 \\
\hline
\end{tabular}

Source: www.andi.dz accessed on 2012

According to the table.4, the contribution of the FDI in the total of fixed capital formation is too weak, since it reached $2.47 \%$ in 2000 . But, it has witnessed slight progress in 2001 by $9.54 \%, 8.53 \%$ in 2002 , and $9.21 \%$ in 2007 .

Table 4: Shares of FDI in gross national investment (\%)

\begin{tabular}{|c|c|}
\hline YEARS & FDI/GFCF \\
\hline 2000 & 2.47 \\
\hline 2001 & 9.54 \\
\hline 2002 & 8.52 \\
\hline 2003 & 4.82 \\
\hline 2004 & 6.21 \\
\hline 2005 & 7.05 \\
\hline 2006 & 1.09 \\
\hline 2007 & 9.21 \\
\hline 2008 & 1.31 \\
\hline 2009 & 1.06 \\
\hline
\end{tabular}

Source: made by the author according to the FDI and GFCF data from UNCTAD and WORLD BANK accessed on 2012
Therefore it can be said that the ratio of FDI in the total of the fixed capital formation knew unbalanced rates during the period from 2000 to 2009. Although the improvement realized in some years, but the FDI is not that important for Algeria to finance investments, since the state has been relied on the average of the national saving which is considered high as it's shown in the following graph:

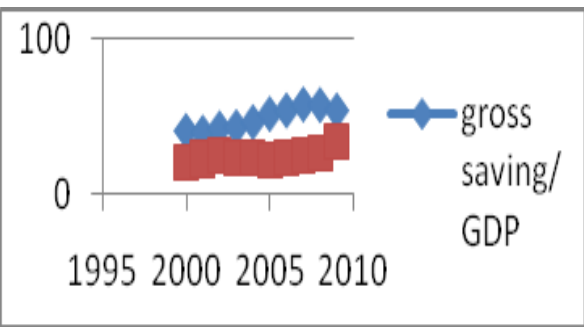

Fig. 2: the evolution of saving and investment rate in Algeria

Source: World Bank, gross saving/GDP \& GFCF/GDP statistics, accessed on 2012

\subsection{FDI Contribution in the Economic growth}

The total of the GDP has increased from USD 54.79 billion in 2000 to approximately USD 81.143 billion in 2011, thus registering fluctuation in the growth rate estimated to $3.52 \%$ average growth rate in the period between (2000-2011), which is considered as a positive factor but it is still out of the expected levels, this is in line with the low level of FDI inflow to Algeria which didn't pass USD 2.746 billion in all this period, although it increased by a great growth rate especially in $(2001,2006,2008)$ which were $(295.53 \%, 66.07 \%, 56.07 \%)$ respectively, since Algeria received in 2001 what's approximately four times more than the received projects in 2000 (from 280.1 million dollars to 1.1079 billion $\$$ in 2001). However and despite the sharp increase of the FDI inflow in this year, the economic growth of this year was estimated 
to $2.59 \%$, therefore it knew only a slight progress from 2000 when it was $2.20 \%$, that means that the realized increase of this year concerning the attraction of FDI doesn't have enough contribution in the realized economic growth in the same year. While in $(2002,2003,2007$, and 2010), the FDI inflow growth rate was negative, this is reverse to what was registered in the realized economic growth rate, because in 2002 when the economic growth rate registered a higher level compared to the previous years, the FDI decreased by $3.87 \%$, the same thing happened in 2003 when the levels of the economic growth estimated to $6.89 \%$ which represents the highest level of economic growth, the FDI inflow realized the lowest level of growth rate. Furthermore, when the economic growth rate decreased from $5.1 \%$ in 2005 to $1.99 \%$ in 2006 , the FDI inflow growth rate increased from $22.58 \%$ in 2005 , to $66.07 \%$ in 2006 , in 2010 also when the economic growth rate registered an augmentation, FDI inflow growth rate registered a very low level which estimated to $-17.56 \%$. From another side, the contribution of the FDI measured by the FDI inflow as a ratio of GDP is still weak, since it knew a varying values during the period 2000-2011, which were limited between $0.51 \%$ in 2000 when the FDI inflow was weak, and $3.58 \%$ as the highest ratio in 2009 , when Algeria knew the highest level of the FDI inflow, and the following graph shows the relationship between the economic growth rate, and the FDI inflow growth rate.

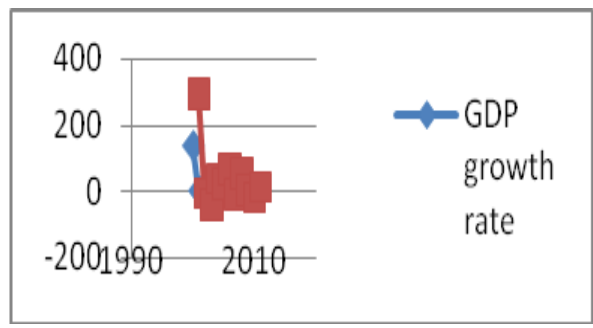

Fig. 3: The evolution of FDI growth rate and GDP

Source: compiled by the author based on the table's data

Table 5: FDI and economic growth in Algeria in the period (2000-2011)

\begin{tabular}{|l|l|r|r|r|r|}
\hline & GDP(USD) & $\begin{array}{l}\text { GDP growth } \\
\text { rate }(\%)\end{array}$ & $\begin{array}{l}\text { FDI } \\
\text { inflow(USD) }\end{array}$ & $\begin{array}{l}\text { FDI inflow } \\
\text { growth rate (\%) }\end{array}$ & $\begin{array}{l}\text { FDI as ratio of } \\
\text { GDP (\%) }\end{array}$ \\
\hline 2000 & 54790060000 & 2.20 & 280100000 & & 0.5112241 \\
\hline 2001 & 56214600000 & 2.599997153 & 1107900000 & 295.5373081 & 1.9708403 \\
\hline 2002 & 58856690000 & 4.70000676 & 1065000000 & -3.872190631 & 1.8094799 \\
\hline 2003 & 62917800000 & 6.899997265 & 633700000 & -40.49765258 & 1.0071872 \\
\hline 2004 & 66189520000 & 5.199991099 & 881900000 & 39.16679817 & 1.3323862 \\
\hline 2005 & 69565190000 & 5.100006768 & 1081100000 & 22.58759497 & 1.5540819 \\
\hline 2006 & 70956490000 & 1.999994537 & 1795400000 & 66.07159375 & 2.530283 \\
\hline 2007 & 73085190000 & 3.000007469 & 1661800000 & -7.441238721 & 2.2737849 \\
\hline 2008 & 74839230000 & 2.399993761 & 2593600000 & 56.07172945 & 3.4655621 \\
\hline 2009 & 76635370000 & 2.399997969 & 2746400000 & 5.891425046 & 3.5837238 \\
\hline 2010 & 79164340000 & 3.300003641 & 2264000000 & -17.56481212 & 2.8598735 \\
\hline 2011 & 81143448101 & 2.499999496 & 2571000000 & 13.56007067 & 3.1684628 \\
\hline
\end{tabular}

Source: UNCTAD and WORLD BANK accessed on 2012 
The table.6 which represents the contribution of FDI in the economy measured by the value of FDI inflow as a ratio of GDP in Algeria and other countries, shows that the rate of the contribution of the FDI in the Algerian economy is the weakest compared to other countries with an average of $2.35 \%$ of FDI as a ratio of GDP during the period from 2002 to 2011, while it's considered high in other countries in comparison to Algeria, among which Saudi Arabia takes the first rank concerning the contribution of the FDI in the economy by $6.86 \%$, then Tunisia by $5.07 \%$, then Egypt, and Morocco by $3.83 \%$ and $3.66 \%$ respectively.

Table 6: FDI as a ratio of GDP in Algeria and some Arab countries

\begin{tabular}{|l|l|l|l|l|l|}
\hline & $\begin{array}{l}\text { Algeria } \\
(\%)\end{array}$ & $\begin{array}{l}\text { Morocco } \\
(\%)\end{array}$ & $\begin{array}{l}\text { Tunisia } \\
(\%)\end{array}$ & $\begin{array}{l}\text { Egypt } \\
(\%)\end{array}$ & $\begin{array}{l}\text { Saudi } \\
\text { Arabia }\end{array}$ \\
\hline 2002 & 1.8 & 2.11 & 3.58 & 0.61 & 0.23 \\
\hline 2003 & 1 & 3.75 & 2.41 & 0.21 & 0.38 \\
\hline 2004 & 1.33 & 8.42 & 2.49 & 1.89 & 0.90 \\
\hline 2005 & 1.55 & 3.5 & 2.94 & 4.52 & 5.33 \\
\hline 2006 & 2.53 & 4.81 & 11.76 & 7.91 & 7.32 \\
\hline 2007 & 2.27 & 5.36 & 5.40 & 8.52 & 9.55 \\
\hline 2008 & 3.46 & 4.50 & 8.83 & 6.52 & 15.32 \\
\hline 2009 & 3.58 & 3.37 & 5.24 & 4.40 & 12.88 \\
\hline 2010 & 2.85 & 2.62 & 4.56 & 3.98 & 10.77 \\
\hline mean & 2.35 & 3.66 & 5.07 & 3.83 & 6.86 \\
\hline & 3.16 & 4.02 & 3.50 & -0.29 & 5.89 \\
\hline & & & & & \\
\hline
\end{tabular}

Source: made by the author according to the data of FDI and GDP collected from UNCTAD and WORLD BANK

\subsection{The contribution of FDI in the ab- sorption of the unemployment:}

According to the statistics set out in the figure.4, it can be noticed that the attracted FDI in Algeria in the period 20022010 had a positive effect on the employment level in terms of creating jobs. The number of the Algerian workers being employed by foreign companies during this period was approximately 39984 workers. Which represents $17.65 \%$ of the total provided job opportunities by investment projects during the same period, versus 186487 job opportunities provided by national projects, which represents $82.34 \%$ of the total job opportunities. So, it is clear that FDI contribution is very low in creating job opportunities compared to the national projects. However, the number of the foreign investment projects during this period estimated to 360 projects, which represents $1.5 \%$ of the total of projects, provided $17.65 \%$ of the total offered job opportunities during the period between (2002-2010). While the local projects number estimated to 24655 projects during the same period, which represents almost $98.5 \%$, offered $82.34 \%$ of the total offered job opportunities for the same period. This is an evidence of the effectiveness of foreign investment projects in providing job opportunities.

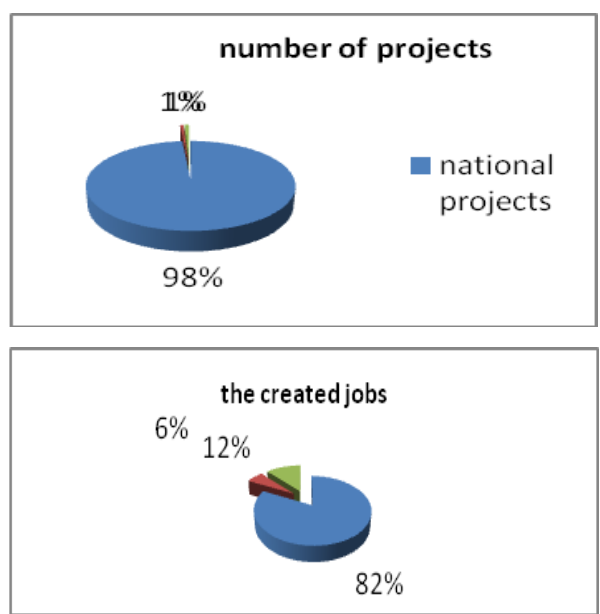




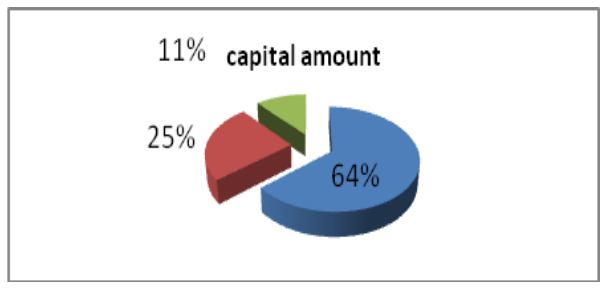

Fig. 4: FDI and job creation during the period 2002-2011

Source: www.andi.dz accessed on 2012

Concerning labour distribution resulting from the foreign investment projects according to the economic sectors during the period (2002-2010), the foreign investment companies in the industrial sector attracted the largest number of the national labour force; since the industrial sector created alone 24318 job opportunities during the period 2002-2010 of a total of 39984 job opportunities offered by the foreign companies among which 1965 were activities related to water and energy, and 12003 were for steel, metal, mechanic and electric industry; service sector came in the second rank with 7314 job opportunities. The companies investing in building, public works and hydraulic sector came in the third position concerning the contribution in creating job opportunities in Algeria by offering only 5141 job opportunities, despite that this sector is considered as labour-intensive sector, but its weak contribution in creating jobs is due to the companies' reliance on the foreign labour brought from their parent countries, such as the Chinese companies activating in the building and public works, which significantly relies on the Chinese labour. The foreign companies investing in the agricultural sector got the last rank, where only 22 positions were offered due to the limited investment projects in this sector during the period (2002-2010) compared to the other sectors.
Table 7: Distribution of workers according to the economic sector

\begin{tabular}{|l|c|c|c|}
\hline Designation & $\begin{array}{l}\text { Projects } \\
\text { number }\end{array}$ & $\begin{array}{l}\text { Amount } \\
\text { in billion } \\
\text { DZD }\end{array}$ & $\begin{array}{l}\text { Created } \\
\text { jobs }\end{array}$ \\
\hline Agriculture & 3 & 1 & 22 \\
\hline $\begin{array}{l}\text { Building, } \\
\text { Public works } \\
\text { and hydraulics }\end{array}$ & 56 & 10 & 5141 \\
\hline Industry & 201 & 528 & 24318 \\
\hline Health & 2 & 5 & 697 \\
\hline Transportation & 13 & 4 & 384 \\
\hline Tourism & 6 & 8 & 2108 \\
\hline Services & 79 & 151 & 7314 \\
\hline Total & 360 & 706 & 39984 \\
\hline
\end{tabular}

Source: www.andi.dz accessed on 2012

\subsection{FDI contribution index ${ }^{[23]}$ :}

The inward FDI contribution index aims to measure the development impact of FDI in the host economy. It shows the contribution of foreign affiliates to GDP (value added), employment, wages and salaries, exports, R\&D expenditures, capital formation and tax payments as a share of host country total (e.g. employment by foreign affiliate as a percentage of total employment). UNCTAD's FDI contribution index contains 79 countries including Algeria which ranked $75^{\text {th }}$, so this rank is considered very low, especially comparing to some countries in the region such as Morocco which is ranked $21^{\text {st }}$ and Egypt $49^{\text {th }}$ among 79 countries.

\section{Conclusion}

Unlike other middle-income economies, for many decades, Algeria has not been able to attract large amounts of FDI, and as foreign investment can help promote economic diversification through diver- 
sify the export (Banga, 2006) ${ }^{[24]}$. These results imply that a fall of FDI in Algeria may hamper the government's efforts to diversify the economy away from hydrocarbons. Therefore because of the weakness of the FDI inflow to Algeria, and the concentration of most of the projects in the hydrocarbon sector, the FDI projects invested in Algeria did not contribute enough in the economy development. In addition to the lack of the absorptive capacity of the Algerian economy (such as: the weakness of the information and communication technology, the difficulty to access the funding, unskilled and inexperienced workers...), All these factors hinder the benefit from the positive effects of foreign direct investment. Since, the FDI spillovers don't appear automatically, but depend on the host counties absorptive capacity (margnus blomsterom \& kokko, 2003). So that, Algeria should follow some procedures, in 11 sectors, to ameliorate the investment environment to attract foreign investors on one hand; and to facilitate the benefit from the advantages of these investments on another hand, through:

- Show the good intention in the execution of fiscal and financial incentives legally stipulated.

- Initializing the infrastructures

- Facilitating the establishment of the projects and getting the local funding, either for foreign or local investments.

- Eliminate the bribery, bureaucracy and the administrative corruption.

- $\quad$ Providing habilitation and scientific training centers for workers that help to assimilate the technology that foreign direct investment brings.

\section{References:}

[1] Azman-Saini, Ahmed Zubaidi Baha rumshah and Siong Hook La, "for- eign direct investment, economic freedom and economic growth: international evidence", Economic Modeling, 27, 1079-1089, 2010.

[2] UNCTAD, "Foreign direct investment, the transfer and diffusion of technology, and sustainable development", Geneva, 2010.

[3] Kjetil Bjorvatn, Hans Jarle Kind and Hildegunn Kyvik Nordås, " the role of FDI in economic development", Nordic journal of political economy, 28, 109-126, 2002.

[4] Roland Craigwell, “ Foreign Direct Investment and Employment in the English and Dutch-Speaking Caribbean", ILO Sub regional Office for the Caribbean, International Labour Organization, 2006.

[5] Magnus Blomström \& Ari Kokko, "the economics of foreign direct investment incentives", WPBundesbank-Conference, 168, 2003.

[6] Laura Alfaro,"foreign direct investment and growth: does the sector mater?",Harvard businee school, 2003.

[7] Magnus Blomström \& Ari Kokko, Op.Cit.

[8] E. Borensztein, J. De Gregorio, J-W. Lee, "How does foreign direct investment affect economic growth?", Journal of International Economics, 45, 115-135, 1998.

[9] Laura Alfaro, Areendam Chanda, Sebnem kelemli-Ozcan, and Selin Sayek., "FDI spillovers, financial markets, and economic development", International Monetary Fund, WP/03/186, 2003.

[10] Niels Hermes and Robert Lensink, "foreign direct investment, financial development and economic growth", journal of development studies, 40, 142-163, 2003.

[11] Mohammed Omran and Ali Bolbol, "foreign direct investment, financial development, and economic growth: 
evidence from the Arab countries” ,Review of Middle East Economics and Finance, VOL. 1, NO. 3, 231-249, 2003.

[12] Christer L Jungwall and Junjie Li, "Financial sector development, FDI and economic growth in China" ,china center for economic growth, working paper series, NO.E2007005, 2007.

[13] Muhhamed Arshad Khan, " Foreign direct investment and economic growth: the role of domestic financial sector" , Pakistan Institute of Development Economics, Working Papers, 18, 2007.

[14] Mohammad Daoudi, "the determinant of FDI in Algeria: empirical study", 10th international conference on recent trends in financing the development, Arab planning institute, Lebanon, 2011.

[15] Najdi Ben Housine, "an analytical study of the investment climate in Algeria" (doctoral thesis, department of economic sciences, faculty of economic and management sciences, university of Constantine (Algeria)), 2006-2007.

[16] UNCTAD, "world investment report: the shift towards services", (New York and Geneva), 2004.

[17] The Arab investment and export credit guarantee corporation, "investment climate in Arab countries", 2011 .

[18] http://eeas.europa.eu/algeria/agreement/in dex_en.htm accessed on 2012
[19] Saadi Yahiya, "the evaluation of FDI climate in Algeria" (doctoral thesis, department of economic sciences, the faculty of economic and management science, university of Constantine (Algeria), 2006-2007.

[20] ANDI is an administrative public agency endowed with a legal status and financial autonomy. It has been placed under the authority of the minister in charge of promoting investments. See the legislative decree No 01-282, containing the role of ANDI agency and it organization, official journal, 55, 2001.

[21] The Algerian national company SONATRACH holds the monopoly in the field of Hydrocarbons, However, for many years; SONATRACH has been able to work in association with foreign firms by negotiating specific contracts or joint venture agreements, for the conduct of its upstream and downstream activities. Investment in this sector is growing rapidly. See ministry delegate for participation and investment promotion, investing in Algeria.

[22] Saadi Yahiya, Op.Cit.

[23] UNCTAD, "world investment report: toward a new generation of investment policies", 2012.

[24] Banga R, "The Export-Diversifying Impact of Japanese and US Foreign Investments in Indian Manufacturing Sector," Journal of International Business Studies Vol. 37:558015668, 2006. 